\title{
The essence of medicine
}

\author{
Writers may tell us their theories on what the essence of medicine is, but it takes actual \\ contact with patients to bring it home to us
}

I do not know whether she expected this: a crowd of 10 curious students in this small, overlit room deep in the bowels of the hospital. She seemed so exposed and frightened in her wheelchair, like a hapless musician unwittingly pushed on stage. The neurologist, standing by her side, was hitting a tendon hammer against his palm.

"Please gather around," he ordered, "and get as close as you can to the patient." We encircled her. A student in the front row took a history.

Anastasia Hayes (who wishes to have her name published) was in her $60 \mathrm{~s}$, with golden hair and thick glasses that magnified her eyes. Her voice was soft, close to a whisper. She explained how, months ago, her left leg became weak. Then the weakness spread to her right hand. "I thought it was just one of those things," she said. Today Anastasia cannot get changed or wash herself unassisted. When the neurologist asked her to walk from one end of the room to the other, she dragged her foot along the floor, as if lugging a rock filled sack. Walking was a Sisyphean struggle, each laboured step making way for the next.

She was asked to lie on the bed. “I don't think I can," she murmured, with a hint of embarrassment. Two students helped her onto the bed. One by one the students performed various tests. They pushed and pulled and hit and scratched, some with confidence, others with timidity. As the crowd admired a performance of Babinski's reflex, I saw Anastasia glance at her watch. It was lonely at her end. An hour had passed.

"I had never heard of motor neurone disease," she said after the physical examination, sitting once again in her wheelchair. "They gave me some leaflets, but I couldn’t bring myself to read them."
"What did the doctor tell you about the disease?" the neurologist asked, crouching next to her. The room was silent.

“He said l'm going to have trouble moving my arms and legs. That l'll have trouble breathing... and swallowing." Anastasia spoke hesitantly, as if remembering a half learnt poem. Then she paused, and the silence became louder. "It's going to be tough."

Behind her glasses, tears welled up in her eyes. She wiped them away and apologised.

Overwhelmed with sadness, I felt like a voyeur, peering through her glasses into the recesses of her stricken soul. I did not understand why she apologised. What rule did she transgress? The rule of optimism? Of stoicism? Of dry eyed composure?

At first, I blamed the neurologist for her distress. Why did he ask the dreaded question? He, of all people, must have known the grim future awaiting her. The medical students, in their penultimate year, knew. Even I knew. I also blamed him for my own discomfort. This was not part of the deal when he invited me to attend his class. This was too close and too real for an academic ethicist. We need distance, physical and emotional, to think objectively on ponderous matters. Detachment is essential to clear thinking.

Earlier that day, on the bus to work, I reread an essay by Richard Selzer, a master of both pen and scalpel, in search of advice for a surgeon friend. The day before my friend had confessed: "I just had to break terrible news to a patient. His tumour was inoperable. But I didn't feel sad at all. I was unmoved."

I eventually found the passage I had in mind. It starts thus: "A surgeon does not slip from his mother's womb with compassion smeared upon him

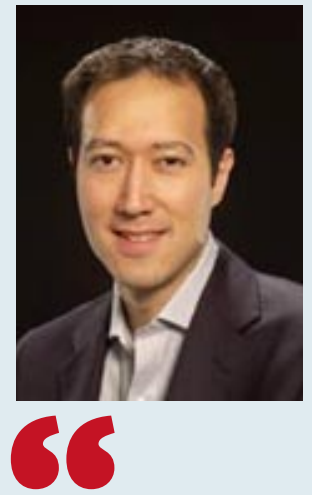

As the crowd admired a performance of Babinski's reflex, I saw Anastasia glance at her watch. It was lonely at her end

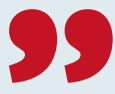

like the drippings of his birth. It is much later that it comes."

Selzer writes that a surgeon's compassion arises from the "cumulative murmuring of the numberless wounds he has dressed, the incisions he has made, all the sores and ulcers and cavities he has touched in order to heal." I emailed the extract to my friend, hoping that he might draw some comfort from it, and went about my day.

Drying the last of her tears, Anastasia said, “I hope l'll be strong enough to cope." The neurologist squeezed her hand. He did not say a word. As I watched him comfort the patient, my thoughts returned to Selzer's essay and his concluding words: "Out of the resonance between the sick man and the one who tends him there may spring that profound courtesy that the religious call Love." As I read this, it occurred to me that Paracelsus in the 16th century and the late French haematologist Jean Bernard also claimed that medicine was grounded on love. There must be some truth in this, I told myself, as the bus arrived at my stop, but the idea remained hazy in my mind, a little too poetic.

In that silent moment of compassion when the neurologist squeezed Anastasia's hand, even in the presence of 10 medical students, I caught a glimpse of it. It was more subtle even than the patient's barely visible fasciculation. The words of Paracelsus, Bernard, and Selzer, which hours earlier sounded fuzzy, now rang out with a newfound clarity. I saw, for the first time, the very essence of medicine.

Daniel K Sokol is lecturer in medical ethics and law, St George's,

University of London daniel.sokol@talk21.com

Patient consent obtained. 